\title{
RECENZJE
}

Klio. Czasopismo poświęcone dziejom Polski i powszechnym PL ISSN 1643-8191, t. 26 (3)/2013, s. 263-295

\section{Janusz Korzeniouski, Małgorzata Machałek, Edukacja obywatelska w szkole. Teoria i praktyka, Wydawnictwo Naukowe PWN, Warszawa 2011, ss. 358}

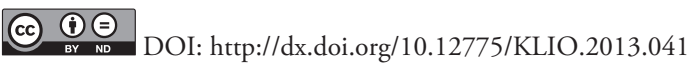

$F_{\text {Korzeniowskiego i Małgorzaty Machałek została wydana nakładem }}^{\text {duka }}$ Wydawnictwa Naukowego PWN jako drugi w serii podręcznik akademicki po Edukacji historycznej Ewy Chorąży, Danuty Konieczki-Śliwińskiej i Stanisława Roszaka. Sam fakt, że to jedyny na polskim rynku podręcznik dydaktyki wiedzy o społeczeństwie, jak również oryginalność, nowoczesność i wysoki poziom Edukacji historycznej stanowią dobrą reklamę recenzowanej pozycji.

Cóż z tego, skoro jej lektura przynosi rozczarowanie. Dlaczego? Nie tylko dlatego, że jest niechlujnie wydana. Już na okładce możemy przeczytać, że to „kompendium wiedzy z zakresu szkolnej edukacji historycznej!" [wykrzyknik w oryginale] - najwyraźniej korzystano z poprzedniej ksiązki. Wewnątrz zaś roi się od błędów ortograficznych, gramatycznych, stylistycznych i niedoróbek w składzie (np. s. 143, przypis 14; tabela 3 na s. 190-191 i wiele innych). Jest to nie tylko irytujące, ale też utrudnia dotarcie do źródeł (gdy w przypisach zmieniane są nazwiska - np. Alicja Szeląg zamiast Szerlag (s. 19) - imiona, adresy internetowe) i zrozumienie sensu tekstu oraz zniekształca przekaz informacji. Dowiadujemy się np., że krótka wycieczka ma trwać 14 godzin (s. 257; zapewne chodziło o 1-4 godziny), a próba do badania ankietowego powinna liczyć 2030 osób (s. 122; chodziło zapewne o 20-30 osób). 
Nie tylko dlatego, że raz po raz można natknąć się na błędy merytoryczne, które utrudniłyby studentowi uzyskanie zaliczenia z dydaktyki. Czytamy np. o „pomocach” zamiast „środkach dydaktycznych” (s. 58), wśród metod nauczania wymienia się zaś odrębnie „pracę grupową” (s. 66 i n.), a odrębnie - pracę pod kierunkiem, „która polega na cichej pracy uczniów wykonywanej pod kontrolą nauczyciela" (s. 103). W przykładowych pogadankach pada po jednym pytaniu (s. 64). Mylone są i mieszane cele oraz metody: „Kształcenie umiejętności wymaga większej ilości czasu na opanowanie nowych treści niż w przypadku pracy metodami podającymi” (s. 65). Poleceniem przed lekturą jest tylko: „Przeczytaj niżej zamieszczony tekst" (s. 233), zaś właściwe zadanie pojawia się dopiero pod spodem. Autorzy bardzo dowolnie podeszli do sformalizowanej z zasady metody webquestu (s. 179-181): wprowadzenie (zarys stosunków Polski z sąsiadami w XX w.) w żaden sposób nie zaciekawia uczniów, choć powinno; informacje o kolejnych etapach pracy nad zagadnieniem znajdują się nie w dziale „proces”, lecz „zadanie” (które ma dawać ogólne pojęcie o pożądanych wynikach pracy); co więcej, generalne ujęcie tematu nie ma charakteru projektu. Jeśli zaś chodzi o projekt jako taki, to jego celem może być, zdaniem autorów, „zebranie i usystematyzowanie informacji o zagadnieniach” lub rozwiązanie problemu (s. 124), podczas gdy literatura przedmiotu mówi o ujęciu problemowym jako istocie tej metody. W charakterystyce pokera kryterialnego (s. 82-83) zabrakło informacji o ograniczonej liczbie miejsc na poszczególnych polach, co pozbawia tę grę dydaktyczną głębszego sensu (skoro dowolną liczbę czynników można uznać za kwestię pierwszorzędna). Wprowadzając pojęcie pytań kluczowych, pominięto ich funkcję motywacyjną i odniesienie do szerszej wiedzy oraz otaczającego świata - co widać także w podanych przykładach takich pytań (s. 188): „Po co istnieją partie polityczne?”, „Dlaczego prawa człowieka są regulowane przez umowy międzynarodowe?” - są to zwykłe pytania ogólne. Spory bałagan panuje w kwalifikacji poszczególnych osiągnięć uczniów do poziomów taksonomicznych (zapamiętywanie, rozumienie, umiejętności). Materiał ze s. 192194 może służyć jako ćwiczenie w wyszukiwaniu typowych błędów - ale nic nie wskazuje, by był to zamiar autorów. Jeśli np. zapiszemy, że „uczeń potrafi wymienić funkcje państwa” - to nie chodzi nam przecież o umiejętność wymieniania, tylko o zapamiętanie funkcji. Odwrotnie, w przykła- 
dowych celach operacyjnych na s. 50 „wyjaśnia i stosuje pojęcia” zostało zakwalifikowane jako „zapamiętywanie”, choć już same nazwy czynności wskazują na rozumienie i stosowanie.

Książka rozczarowuje również dlatego, że - wbrew deklaracjom ze wstępu - unika stawiania istotnych problemów, przed którymi staje młody (i nie tylko młody) nauczyciel, i pokazywania sposobów ich rozwiązywania. I nie wynika to z braku miejsca, gdyż równocześnie całe strony zajmują przedruki dokumentów urzędowych i informacje, do których bez trudu można dotrzeć z innych źródeł (choćby znaleźć w Internecie). Na przykład zamieszczono drobiazgową notatkę dotyczącą rodzajów konfliktów społecznych jako wynik pracy pod kierunkiem (s. 110-111), pominięto natomiast całkowicie kwestię tego, jak taką pracę dobrze zorganizować - np. jak sformułować i zadać pytania, jak sprawdzić wyniki, by uczniowie rzeczywiście skorzystali z lekcji. Podobnie, brak wskazówek: jak przeprowadzić dramę (w jednej z propozycji znajdujemy tylko rysunek sali sądowej, w innej - ogólny temat: „sesja rady gminy”, s. 114-115) albo lekcję kreatorską z zakresu wiedzy o społeczeństwie (s. 234-236), na co zwracać uwagę, polecając uczniom gromadzenie materiałów w portfolio (s. 121: w przykładach są tylko tematy, np. „zawody przyszłości”), jakich wskazówek udzielić przed przeprowadzeniem wywiadu (czytamy tylko: „nauczyciel zapoznaje uczniów z zasadami przeprowadzania wywiadów", s. 121) czy opracowaniem ankiety (na s. 123 mamy temat: „Rola subkultur w życiu młodzieży”, widnieje odniesienie do podstawy programowej i nic więcej). Zorganizowanie wycieczki szkolnej sprowadza się do zabiegów technicznych, z pominięciem kwestii merytorycznych: jak ją powiązać z materiałem wiedzy o społeczeństwie (z recenzowanej książki można odnieść wrażenie, że wystarczy, jeśli uczniowie przyjrzą się budynkowi sejmu albo Parlamentu Europejskiego - nota bene, ciekawe, jak często klasy szkolne odwiedzają Brukselę lub Strasburg). Pięćdziesiąt pięć (!) stron zajął przedruk autorskiego programu nauczania wiedzy o społeczeństwie. Jak jednak autor go sformułował, jakie czynniki uwzględnił, z jakich materiałów korzystał, dlaczego wybrał takie, a nie inne rozwiązania - tego się czytelnik nie dowie. Muszą mu wystarczyć stwierdzenia, że to trudne zadanie, wymagające doświadczenia i że program autorski powinien pozostawać w zgodzie z podstawą programową. Więcej miejsca poświęcono na przedrukowanie standardów wymagań egzamina- 
cyjnych (s. 216-221) niż na - bardzo lakoniczne w efekcie - wskazówki, jak dobrze przygotować ucznia do matury (np. „systematycznie doskonalić umiejętność krytycznego myślenia” - s. 223). To samo dotyczy olimpiad przedmiotowych (s. 255-257), gdzie najdłuższy jest cytat ze stosownego rozporządzenia, nieco krótsze - omówienie tematyki Olimpiady Wiedzy o Polsce i Świecie Współczesnym, mającej najdłuższą tradycję wśród tego rodzaju przedsięwzięć, a na zakończenie przytoczono nazwy kilku innych olimpiad, powiązanych z wiedzą o społeczeństwie, ich organizatorów i linki do stron internetowych.

Takie właśnie urzędowe, a raczej urzędnicze, podejście do nauczania, a nauczania wiedzy o społeczeństwie w szczególności, budzi moje największe rozczarowanie i sprzeciw. Autorzy żonglują aktami prawnymi, definicjami podobnymi do wyjaśnienia znaczenia lufy ze starego dowcipu wojskowego („lufa to nagwintowany słup powietrza oblany stalą”): „wycieczki szkolne to zorganizowane wyjścia poza teren szkoły mające cele dydaktyczne i wychowawcze" (s. 257), a ocenianie "jest procesem ustalania i komunikowania ocen szkolnych" (s. 184); mentorskim tonem przedstawiają zalecenia (s. 230: „Właściwe zaplanowanie i przeprowadzenie lekcji jest podstawowym obowiązkiem [...] nauczyciela”). W ten sposób dydaktyka akademicka, reprezentowana przez omawiany podręcznik, stara się uczynić ze swoich słuchaczy „realizatorów programu” aktualnie ustalonego przez władze. A przecież nauczyciel powinien przede wszystkim uczyć, a nie realizować wytyczne; uczyć przedmiotu, a nie programu. Powinien wiedzieć, po co to robi, że nie wynika to $\mathrm{z}$ tego, iż został nałożony na niego taki obowiązek. I powinien mieć świadomość, dlaczego uczy tak, a nie inaczej. Jego przygotowanie powinno być na tyle uniwersalne, by potrafił odnajdować się także w zmieniającej się rzeczywistości szkolnej. To prawodawca powinien korzystać z dorobku nauki (w tym nauk pedagogicznych), a nie dydaktyka opierać się na aktach prawnych. Autorzy omawianej książki jeśli zaś proponują debatę o karze śmierci, to nie dlatego (w świetle ich argumentacji), że to ważny problem, okazja do kształtowania i weryfikowania systemu wartości, do wyrażania własnych przekonań i przyjmowania lub odrzucania przekonań innych, ale dlatego, że temat ten pasuje do podstawy programowej (IV etap, zakres rozszerzony, punkt $9-$ s. 71). Czy jeśli podstawa programowa się zmieni, to o karze śmierci nie warto będzie dyskutować? Czy ustalając 
kryteria ocen z wiedzy o społeczeństwie, należy kierować się przede wszystkim „aktualnie obowiązującymi przepisami prawnymi dotyczącymi oceniania, Podstawa programowa kształcenia ogólnego z wiedzy o spoteczeństwie, standardami wymagań egzaminacyjnych, wybranym programem nauczania [...]" (s. 189), czy jednak bardziej ogólnymi zasadami pedagogicznymi?

Podstawą dydaktyki powinny być wyniki badań naukowych - o nich jednak w recenzowanej pracy się nie wspomina (skąd np. wiadomo, że najlepiej pracuje się w grupie liczącej 4-5 osób? - s. 66). Niewiele jest odwołań do innej literatury przedmiotu niż syntezy i opracowania encyklopedyczne. Zupełnie nieobecny jest dorobek światowy, obcojęzyczny. Przecież „piramida zapamiętywania" nie pochodzi od Małgorzaty Taraszkiewicz (s. 60). Nie widać toczonych dyskusji o istocie przedmiotu, odzwierciedlonej choćby w tytule książi: czy ma to być wiedza o społeczeństwie, czy edukacja obywatelska. Nawet jeśli w praktyce daje się pogodzić jedno z drugim - co zaleca ministerstwo - to powinna być obecna szersza refleksja na ten temat. Razi niezwykle tradycyjne (żeby nie powiedzieć „tradycjonalistyczne”) podejście do podręcznika jako podstawowego środka dydaktycznego, który w przypadku wiedzy o społeczeństwie wymaga ciągłej aktualizacji (s. 145). Tymczasem we wspótczesnych koncepcjach nauczania-uczenia się bardzo często odchodzi się od podręcznika, zwłaszcza rozumianego jako kompendium wiedzy. Niepokojące jest też sprowadzanie analizowanych tekstów do źródeł informacji, które można odnaleźć, ocenić ich wiarygodność i wykorzystać - podczas gdy współczesna dydaktyka, idąc za metodologią historii, podkreśla, że w zasadzie każdy przekaz niesie zarówno informację, jak i interpretację, które nieraz trudno rozdzielić. I właśnie to należałoby uczniom pokazywać, nawet bez intencji oceniania danej interpretacji, lecz po to, by zdawali sobie z niej sprawę. Rozdział poświęcony technologii informacyjnej został umieszczony na końcu środków dydaktycznych, jako swego rodzaju „kwiatek do kożucha”, a przykładowe scenariusze większości innych lekcji z powodzeniem można by zrealizować $\mathrm{w}$ dziewiętnastowiecznej izbie szkolnej. Nota bene, PowerPoint nie jest jedynym programem do tworzenia prezentacji multimedialnych i nie ma uzasadnienia dla promowania właśnie jego w publikacji akademickiej (m.in. s. 134, 135).

Powyższe zastrzeżenia nie oznaczają, że Edukacja obywatelska jest pracą bezwartościową. Są tu fragmenty, które z pewnością polecę jako lektu- 
rę studentom - np., jak operacjonalizować cele nauczania, tworzyć testy, formułować cele wychowawcze lekcji albo kryteria oceny poszczególnych wytworów pracy ucznia. Owszem, często są to streszczenia lub przedruki innych opracowań, ale zrobione rzetelnie, a przy tym przystępnie. Wierzę, że zebrany w pracy materiał można wykorzystać, uzupełnić, przedyskutować i przeredagować tak, by powstał akademicki podręcznik dydaktyki wiedzy o społeczeństwie, a może nawet edukacji obywatelskiej, z prawdziwego zdarzenia. Będę czekała na drugie wydanie.

Joanna Wojdon (Wrocław) 